Turyzm 2020, 30/1

Jacek Kaczmarek

https://orcid.org/0000-0003-1750-1592

Uniwersytet Łódzki

Instytut Geografii Miast i Turyzmu

Zakład Geografii Miast

jacek.kaczmarek@geo.uni.lodz.pl

\title{
TURYSTYKA LITERACKA W UJĘCIU ALEATORYCZNYM NA PRZYKŁADZIE HAWANY
}

\begin{abstract}
Abstrakt: Pojęcie „turystyka literacka” jest określeniem stabilnym, zazwyczaj nie wzbudza kontrowersji przedmiotowych. Dobrze wpisuje się w pozytywistyczny porządek myślenia o rzeczywistości turystycznej. Dokonana analiza kubańskich dzieł literackich oraz przeprowadzone badania terenowe w Hawanie wskazały na konieczność rekonstrukcji używanych definicji „turystyki literackiej”. Ma ona bowiem wiele kontekstów i nie można przyjąć jednego, niepodważalnego określenia. W artykule zaproponowano podejście aleatoryczne, w którym wykorzystano przypadek podczas eksploracji przestrzeni literatury w Hawanie.
\end{abstract}

Słowa kluczowe: turystyka literacka, przypadek, claves, Hawana.

\section{WSTĘP}

Świat turysty to kompleks zdarzeń - wszelkich zdarzeń, które minęły, trwają, nadejdą. Każde z nich jest sensowne i prawdopodobne, dlatego można stwierdzić, że są lub że ich nie ma. Zdarzenia dzielą się na celowe i incydentalne. Rzeczywistość doświadczana podczas podróży staje się światem turysty, który ludzie potrafią wyrazić w słowach. Turystyka literacka bywa zatem dostrzeganiem rzeczywistości w nieśpiesznym wędrowaniu $\mathrm{w}$ świecie zdarzeń celowych i incydentalnych $\mathrm{w}$ przestrzeni literatury, podczas podróży sprowokowanych dziełami literackimi (zob. Arystoteles, 2003; Wittgenstein, 2012). Celem autora artykułu jest wyznaczenie nowych horyzontów w utrwalonej w literaturze przedmiotu koncepcji turystyki literackiej. Wśród licznych opracowań naukowych, w których badacze zdefiniowali turystykę literacką oraz jej zakres empiryczny i analityczny, zwraca uwage publikacja z wyeksponowanym wątkiem metodologicznym (Roszak, Godlewski, 2013). Zaproponowano w niej inspirujące podejście do oceny i prezentacji potencjału turystycznego na obszarach powiązanych z podróżami literackimi. Jeżeli jednak wskazana droga rozwiązań krajoznawczych zostanie rozbudowana o kolejne wątki problemowe, otrzymamy następujące konteksty turystki literackiej:

- metodologia badań turystyki literackiej;

- metodyka organizowania przestrzeni literackiej;
- systematyka postaw turystów wobec dzieła i przestrzeni, w której zostało ono umiejscowione przez autora. W artykule wyeksponowano trzeci aspekt problemowy, tzn. doświadczanie przestrzeni w konkretnym kontekście literackim i geograficznym. Przyjęto bowiem, że intrygującym motywem analitycznym powinno być zrozumienie postaw czytelnika-turysty podczas podróży do źródeł utworów literackich. Czytelnika-turystę umiejscawiano w centrum dociekań badawczych już wcześniej w opracowaniach humanistycznych. Czytelnik bywa bowiem współautorem interpretacji dzieła. To właśnie dzięki aktywnej lekturze utwory żyją. Przyjęcie takiej konwencji odbioru literatury doprowadziło do następującej konstatacji - „Czytelnik jako aktywny czynnik interpretacji stanowi część generatywnego obrazu samego tekstu" (Eco, 1994, s. 9). Autor dzieła często rzuca wyzwanie czytelnikowi i nie powala mu pozostać biernym odbiorcą utworu. Wzywa czytelnika - który nie powinien być widzem, ale kreatywnym partnerem (Czermińska, 2000) - do aktywnej interpretacji tekstu. Cel wyprawy literackiej jest bardzo ważny, jednak to nie miejsce docelowe może być istotą podróży. Także sama wędrówka, poszukiwanie śladów narracji w przestrzeni ma olbrzymie znaczenie. Takie podejście wymaga jednak adekwatnych perspektyw metodologicznych (Zajas, 2008). 
Głównym wątkiem myślenia w sugerowanym postępowaniu badawczym będzie wprowadzenie kategorii przypadku do turystyki literackiej. Oparte na przypadku podejście aleatoryczne zostanie omówione na przykładzie literatury, której główną areną wydarzeń uczyniono Hawanę. Miasto zostało ukazane w dwóch kontekstach historycznych. Pierwszy z nich to fabuła osadzona w latach 50. XX w. Materiałem źródłowym były utwory literackie autorstwa G. Cabrery Infantego - Moja wina, bo ja tańczyłem cza-cze i Trzy pstre tygrysy (Cabrera Infante, 2009, 2016). Natomiast drugi kontekst historyczny dotyczy lat 90. XX w. Wykorzystano przejmujący obraz Hawany przedstawiony przez P.J. Gutiérreza w Brudnej trylogii o Hawanie (Gutiérrez, 2019). Natomiast studia terenowe prowadzono w drugiej dekadzie XXI w. Ich celem było wykorzystanie ujęcia aleatorycznego w doświadczaniu przez czytelnika-turystę przestrzeni literatury w Hawanie. Podstawową metodą badawczą uczyniono podejście autoetnograficzne (Botterill, Platenkamp, 2012). Studia terenowe wymagają bezpośredniego zaangażowania autora $\mathrm{w}$ interpretację utworu literackiego w miejscu jego „dziania się” (fot. 1).

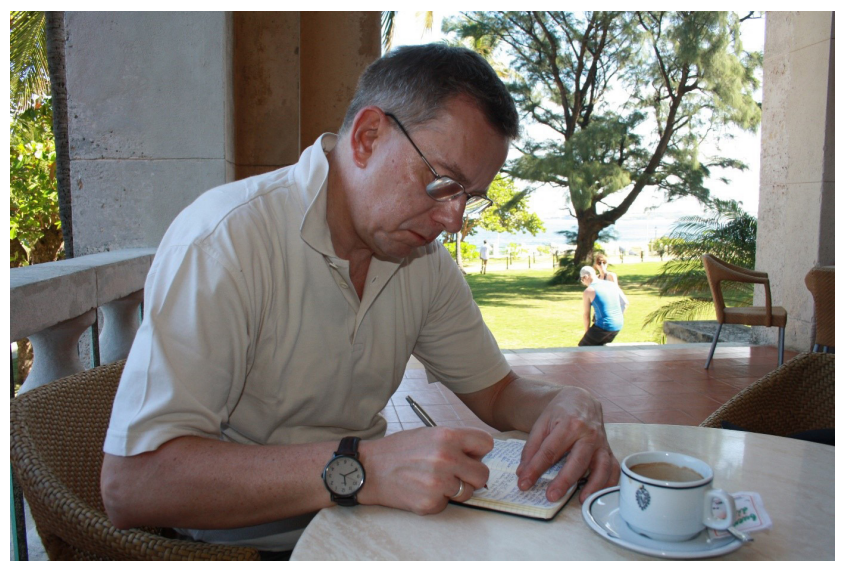

Fotografia 1. Hotel Nacional de Cuba - prace terenowe Źródło: S. Kaczmarek (luty 2015)

Studia autoetnograficzne uzupełniono „odsłonięciem fenomenologicznym”, które pozwala dostrzec spoiwo przestrzeni i czasu, jako miejsca wydarzania chwili (Heidegger, 1996). Tą chwilą bywa wkroczenie do świata utworu w bezpośrednim doświadczeniu przestrzeni literatury. W innym podejściu ontologicznym wspomniane „odsłonięcie fenomenologiczne” bywa zakorzenione w momencie istotnościowym (Stein, 1995). Geneza podjętych badań, tzn. dobór literatury, podróż literacka, wykorzystane metody terenowe, zawiera się w znanym stwierdzeniu Kubusia Puchatka: „Bo układanie Wierszy i Piosenek to nie są rzeczy łatwe, które się łapie w powietrzu. To one cię łapią i wszystko, co można zrobić, to pójść tam, gdzie one mogłyby cię znaleźć" (Milne, 1987, s. 125). A Hawana jest bez cienia wątpliwości miastem, które chwyta czytelnika, turystę, badacza i prowadzi drogą aleatorycznego doświadczenia do zrozumienia życia mieszkańców w perspektywie dzieł literackich. Nie pozostaje w tej sytuacji nic innego, „jak ruszyć naprzód i ów czytelnik, zawsze stojący z boku tekstu, czy raczej siedzący mu na karku albo depczący po piętach, umieszczony zostaje w tekście" (Eco, 1994, s. 15).

\section{DOŚWIADCZANIE PRZYPADKU}

Przypadek określa zdarzenia incydentalne i jest przede wszystkim pojęciem statystycznym, mającym jednak niepodważalny wpływ na życie każdego człowieka. W niniejszym artykule rozważania rozpoczną się zatem od przykładów wpływu przypadku na konteksty zdarzeń zapisywanych na kartach literatury pięknej. Na początek warto zanurzyć się w intrygujące strofy, które zapisał F. Pessoa jako Álvaro de Campos (Pessoa, 2016, s. 189):

Kwitnienie przypadkowego spotkania Tych, którzy na zawsze mają pozostać sobie obcy...

Jedyne spojrzenie posłane bez zainteresowania posłane przelotnie

Przez przypadkową nieznajomą...

Zainteresowane spojrzenie dziecka prowadzonego za rękę

Przez roztargnioną matkę...

Przypadkowe słowa zamienione Z przypadkowym podróżnym W przypadkowej podróży...

Wielki ból, że wszystkie rzeczy są fragmentami... Droga bez końca...

Nieco inne spojrzenie na przypadek zostało zaprezentowane w układance, jaką jest dzieło J. Cortázara Gra w klasy, w przekładzie Z. Chądzyńskiej: „[...] przypadkowe spotkanie jest czymś najmniej przypadkowym w naszym życiu i że tylko wyznaczają sobie rendez-vous ci, którzy pisują do siebie na liniowanym papierze, a pastę do zębów wyciskają do samego końca tubki" (Cortázar, 2013, s. 8). Czy przypadek jest rzeczywiście przypadkowy? Czy jak zauważa Wittgenstein (2012, s. 5-6), skoro już się wydarzył, to musiał już być wpisany w istotę bycia:

$2.012 \mathrm{~W}$ logice nic nie jest przypadkowe. Jeżeli rzecz może wystąpić w stanie rzeczy, to jego możliwość musi już być w niej przesądzona.

2.0121 [...] Jeżeli rzeczy mogą występować w stanach rzeczy, to musi to już w nich tkwić.

2.013 Każda rzecz jest niejako w przestrzeni możliwych stanów rzeczy. 
Możemy zatem domniemywać o konieczności przypadku. Jest on zapisany w scenariuszu przebiegu zdarzeń. Czym bowiem jest zdarzenie? To pojęcie pierwotne. Jednak możemy przyjąć, że zdarzenia są realnymi sytuacjami, które mają jednoznaczne parametry czasowe i przestrzenne. Są definiowane jako przedmioty czasowo-realne, doświadczane empirycznie i mające swoją historię, tzn. przebieg i trwanie (Kaczmarek, 2005; Kobiela, 2011). Każde zdarzenie, jak już wspomniano we wstępie artykułu, jest sensowne i prawdopodobne. W przedstawionych przykładach literackich zawiera się idea aleatoryzmu, czyli losowości wszystkiego, co się zdarza w codzienności, praktyce gospodarczej, sztuce, myśleniu i egzystencji każdego z nas. Przypadek jest podstawą rachunku prawdopodobieństwa. Matematyka to nauka, w której ujęcia aleatorycznego nie sposób uniknąć. Wracając jednak do sztuki i jej różnych dziedzin, należy zauważyć, że wędrowanie w miejskiej przestrzeni literatury może zaskakiwać. Może wytrącać przechodnia z dotychczasowej rutyny doświadczania przestrzeni. Różne zbiegi okoliczności pojawiają się w każdym miejscu:

Jaki jest Rzym? Właśnie taki. Wychodzisz z domu i nie wiesz, co zobaczysz po drodze. Dzisiaj idę do tego samego baru co zwykle i odkrywam na dachu nad barem chińskie figury, jak słynne posągi cesarskiej armii z terakoty. Wchodzę do biura, a tam przed drzwiami karteczka z informacja, że właściciel domu jest ludożercą (Mikołajewski, 2011, s. 411-412).

Zaskoczenie i zdziwienie wprawiają wędrowca w zakłopotanie. Przypadek wprowadza zamieszanie $\mathrm{w}$ orientacji przestrzennej. To z kolei sprawia, że zachodzą kolejne przypadki. W ten sposób można poznawać obce miasta, pozostawiając $w$ hotelu banalny, powtarzalny przewodnik turystyczny. Przypadek wyznacza wówczas trasę zabłądzenia turystycznego w zmiennych przestrzeniach literatury: „Wśród wielu rodzajów zagubienia w Rzymie jest również to zwykłe, gdy oto, wędrowcze, odkrywasz, że nie wiesz, gdzie jesteś. Prócz absolutnego braku zmysłu orientacji jego źródłem jest dla mnie Tybr - jego zwroty, które obracają świadomość o nietypowe rozwarcie kątów" (Mikołajewski, 2011, s. 17). Przypadek wiedzie do zagubienia się w przestrzeni, ale także do błądzenia we własnej świadomości. Turysta literacki odkrywa świat, którego korzenie tkwią w dziele, ale ciąg dalszy może być zaskakujący i nieprzewidywalny. Podróż śladami literatury bywa zatem niespodziewana, również niebezpieczna, ponieważ zmienne stany świadomości turystycznej mogą nam ukazać, kim jesteśmy w rzeczywistości.

W filmie jako kategorii sztuki również rozpatrywano wpływ przypadku na ludzki los. Owszem, przypadek może wyznaczyć różne drogi ludzkiego wędrowania w nieprzyjaznym świecie, ale stała, niezmienną wartością pozostaje nasza postawa wobec zmiennej rzeczywistości. Człowieczeństwo powinno być podstawową wartością, niezależnie od tego, kim jesteśmy i w jakich okolicznościach się znaleźliśmy. Zagadnienie to ukazał K. Kieślowski w Przypadku. Niezależnie od tego, jaką drogę wskaże nam los, to od naszych wyborów zależy, kim jesteśmy, jakimi ludźmi się stajemy. Starożytni traktowali żywot ludzki jako tragedię, której scenarzystą był los, tkający płótno przypadkowego życia. Przyoblekając się w tę tkaninę losu, można było jednak być człowiekiem porządnym lub łotrem. Bywa, że rzut monetą decyduje o naszej przyszłości i nasze dalsze losy kreowane są przez przypadek:

Bohater Kartografa Guillaume'a Jana, młody paryżanin Lazare, ze znalezioną na ulicy mapą i niezaznajomiony z realiami środkowo-wschodniej Europy, bez pieniędzy i znajomości języka przemierza jako autostopowicz - a często pieszo - Bośnię, Albanię, Rumunię, Mołdawię, Ukrainę, Czechy. Jego trasa powrotu z Sarajewa do Paryża jest zawiła, gdyż zależna od przypadku i od napotkanych ludzi. Jego przewodnikami w drodze są najczęściej emigranci wracający na urlop z Belgii, Włoch czy Francji, ale też muzykanci grający na weselach, artyści z trupy cyrkowej, amerykański misjonarz, rolnik poszukujący w sezonie rąk do pracy przy pomidorach (Konończuk, 2014, s. 183-184).

Bohater Kartografa kreśli trasę swojej wędrówki na odwrocie znalezionej mapy. Powstaje w ten sposób nowa mapa, której legendą są przypadkowe spotkania i następujące po nich wybory dróg prowadzących w efekcie do Paryża. Lazare nie korzysta z przewodników turystycznych, on tworzy nowy przewodnik. Życie, literaturę i turystykę określa przypadek. Obliczona nadzieja matematyczna nie pasuje do naszego życia, do przeżywanych przez nas podróży. W ujęciu aleatorycznym pierwszeństwo poznawcze mają bowiem zdarzenia o niewielkim prawdopodobieństwie zaistnienia. Czy podczas podróży może zdarzać się coś, co jest mało prawdopodobne? Należy stwierdzić, że tak, ponieważ istnienie zdarzeń znajdujących się na obszarze niewielkiej istotności statystycznej nie jest wykluczone. Warto pytać dalej, czy zdarzenia o niewielkim prawdopodobieństwie wystąienia mają znikomy wpływ na wyjaśnianie badanej rzeczywistości. Zdaniem rozhisteryzowanych statystyków takie zdarzenia powinny zostać odrzucone w procesie wnioskowania probabilistycznego. Okazuje się jednak, że nie można odrzucić zjawisk, które znajdują się poza granicami istotności statystycznej, tzn. są w obszarze, gdzie $p<0,05$. Taka istotność statystyczna ma duże znaczenie w turystyce literackiej, zwłaszcza eksponującej znaczenie przypadku. Dlatego w turystyce tego typu trzeba dopuścić prawdziwość epistemologiczną dla zjawisk o niewielkiej istotności statystycznej. Przedstawione wskazania nie są odkrywczą i rewolucyjną konstatacją. Grono profesjonalnych statystyków sugeruje bowiem, 
aby odważnie przekraczać granice małej istotności statystycznej, czyli tam, gdzie p <0,05. Nie należy zatem opierać wnioskowania badawczego tylko na poziomie właściwej istotności statystycznej (Wasserstein, Schirm, Lazar, 2019). Najważniejszymi parametrami turystyki literackiej są zaskoczenie i wyobraźnia, wymagające przekroczenia schematów zawartych w granicach istotności statystycznej, wszak:

żadne marzenie, choćby nie wiedzieć jak absurdalne i niedorzeczne, nie marnuje się we wszechświecie. W marzeniu zawarty jest jakiś głód rzeczywistości, jakaś pretensja, która zobowiązuje rzeczywistość, rośnie niedostrzegalnie $\mathrm{w}$ wierzytelność $\mathrm{i} w$ postulat, i w kwit dłużny, który domaga się pokrycia (Schulz, [b.r.], s. 5).

Marzeń nie sposób zawrzeć w poprawnej reprezentatywności. Ujęcie aleatoryczne zostało dotychczas najlepiej określone i następnie wykorzystane praktycznie w muzyce. Aleatoryzm nie jest jednak zbyt popularnym i dobrze zrozumianym nurtem artystycznym. Należy w pierwszej kolejności określić znaczenie podejścia aleatorycznego, którego sens doskonale wybrzmiewa w kwartecie smyczkowym skomponowanym przez W. Lutosławskiego w 1964 r.:

W utworze tym Lutosławski stosuje technikę tzw. ograniczonego aleatoryzmu, polegającego na takim dopuszczeniu przypadku, aby służył on rytmicznemu i ekspresyjnemu wzbogaceniu muzyki, a równocześnie w niczym nie naruszał pełnej władzy kompozytora nad ostatecznym kształtem utworu. Kwartet składa się z drobnych sekcji (zwanych przez kompozytora „mobilami") wykonywanych w podanej kolejności. Z wyjątkiem synchronicznych miejsc oznaczonych w nutach, każdy z wykonawców gra swoją partię całkowicie niezależnie od pozostałych muzyków. Samodzielność partii jest tak daleko posunięta, że poszczególni wykonawcy nie zawsze muszą wiedzieć, co inni w danym momencie grają. Przy tego rodzaju fakturze niemożliwy jest tradycyjny zapis partyturowy (istnieje więc tylko „swoista księga głosów”), gdyż ścisłe oznaczenie pionu uniemożliwiłoby wykonawcom swobodę $\mathrm{w}$ realizacji własnych temp oraz indywidulnych rubat, przyspieszeń, zwolnień i długości fermat. Tym niemniej oznaczenia w nutach zawierają niezbędne informacje zarówno na temat samej muzyki, jak i koniecznego porozumienia pomiędzy wykonawcami. Kwartet stanowi więc próbę zupełnie nowego sposobu kameralnego muzykowania (Gwizdalanka, 1998, s. 368).

Turystyka literacka, zagrana na nutę aleatoryczna, musi zatem dawać turyście możliwości wyboru drogi, podejmowania decyzji. Szlak literacki czy przewodnik turystyczny powinny zostać zdemontowane. Ich dekonstrukcja powinna doprowadzić do indywidualnego doświadczania odwiedzanego miejsca. Autorzy utworów literackich wykorzystywanych w prowadzonych rozważaniach także sugerują myślenie aleatoryczne podczas tworzenia dzieła, jego interpretacji oraz poszukiwania śladów literatury w konkretnych rzeczywistościach turystycznych (Kaczmarek, Kaczmarek, 2015). Cabrera Infante (2016, s. 373) doradzał stosowanie następującego rozwiązania twórczego:

Razem z książką czytelnik dostawałby zestaw liter do tytułu i parę kostek. Z tych trzech elementów każdy mógłby zrobić swoją książkę. Wystarczałoby rzucać kośćmi. Gdyby wypadły 1 i 3, szukałoby się pierwszego i trzeciego słowa lub słowa numer 4 [...]. Kolejność słów na liście, także arbitralna, podobnie jak ich rozmieszczenie przez czytelnika, zależałaby od rzutu kośćmi. Być może w ten sposób zaczęłyby powstawać prawdziwe wiersze, a poeta były znowu twórcą czy truwerem. Aleatoryczność nie byłaby żadnym przybliżeniem czy metaforą.

Wskazana droga postępowania twórczego trwa w rytmach bachaty, czyli tańca z Dominikany, nawiązującego do tradycji muzycznych tamtejszych chłopów, odwołującego się także do kubańskiego bolera. Jest to taniec zmysłowy, bywa wulgarny, wyraża wrażliwość, zdradę, wyobcowanie, rozpacz, beznadziejność. Istnieje jednak jeszcze inny aspekt rozumienia bachaty - jako hałaśliwej zabawy, żartobliwej rozmowy, dowcipnych ripost. Właśnie ta jej druga strona doskonale oddaje ducha aleatoryzmu, jako że przypadek jest koniecznością naszego życia. Bywa żartem, ironią, celną odpowiedzią i reakcją na różnorakie złośliwości czy ataki. Wędrować ulicami Hawany, szukając przestrzeni literackich, to tańczyć bachatę. Właśnie ten taniec lepiej oddaje ducha aleatorycznej Hawany niż powszechnie wybrzmiewająca tam salsa. Muzyczne rytmy są niewątpliwie owymi „mobilami” z muzyki Lutosławskiego, które dają możliwości wyboru dróg turystycznych w literackiej Hawanie. Dźwięki claves pozwalają turyście konstruować swoje własne interpretacje w turystyce literackiej wśród zadziwiających budowli tego zaskakującego miasta:

To prawda, że muzyka kubańska jest prymitywna, ale posiada radosny urok, zaskakuje zawsze mocnym uderzeniem i czymś nieokreślonym, poetyckim, co leci w górę wysoko, wraz z marakasami i gitara, podczas gdy bębny przykuwają ją do ziemi, a claves - dwie pałeczki, które wytwarzają muzykę - są jakby stałym horyzontem (Cabrera Infante, 2016, s. 199).

Owe rytmy to ten stały horyzont zwiedzania Hawany w sytuacji, kiedy pojawia się wiele wykonań, czyli doświadczeń literackich w przestrzeniach kubańskiej stolicy. Pokazane przykłady muzyczne spod karaibskiego nieba wskazują wyraźnie, że turystyka literacka ma wiele odcieni i nie sposób jej zadekretować w jednej definicji. Potrzebna jest więc rekonstrukcja pojęcia ,turystyka literacka”. 


\section{ZAKRES TURYSTYKI LITERACKIEJ}

Obszar badawczy i pojęciowy turystyki literackiej ma stabilne granice poznawcze. Wykorzystywane zazwyczaj definicje turystyki kulturowej nie budzą kontrowersji, mają utrwalony zakres przedmiotowy. Dobrze wpisują się w pozytywistyczne podejście do badanej rzeczywistości turystycznej. W polskim piśmiennictwie naukowym podstawową definicję turystyki literackiej w kontekście produktowym zaproponował Zmyślony (2001, s. 22-23):

[...] turystyka literacka obejmuje wszystkie czynności towarzyszące krótkotrwałemu przemieszczaniu się osób do miejsc docelowych związanych z dziełami literackimi i ich twórcami, poza miejscem stałego zamieszkania i pracy, oraz pobytowi w tych miejscach. Do najważniejszych funkcji, jakie może pełnić aktywność turystyczna wynikająca z fascynacji literatura, należą: funkcja poznawcza i kształceniowa, funkcja edukacji kulturowej, funkcja etniczna.

Kolejnego uściślenia zakresu pojęciowego turystyki literackiej dokonała Buczkowska (2008, s. 58): „Literacka turystyka kulturowa to forma turystyki kulturowej, której główną motywacją jest docieranie do określonych miejsc związanych w różnorodny sposób z literaturą (literaturą piękną i literaturą faktu), umożliwiającą szeroki kontakt z kulturą". Na jeszcze inne aspekty definicji turystyki kulturowej zwrócił uwagę Mikos von Rohrscheidt (2008, s. 68), podkreślając znaczenie kontekstów podmiotowych oraz osobistych refleksji podczas podróży: „[...] kulturowa podróż literacka jako podróż o charakterze turystycznym, w której tematem wiodącym jest osoba i dzieło twórcy lub kilku twórców, zaś odwiedzane miejsca stanowią okazję do refleksji nad jego (ich) dziełem". Przedstawione stanowiska autorskie zebrał i uporządkował Stasiak (2009, s. 224), sugerując następujące rozstrzygnięcie w zakresie definiowania turystyki literackiej:

Turystyka literacka jest ważną częścią turystyki kulturowej, obejmującą wszelkie podróże turystyczne śladami wielkich twórców literatury i ich dzieł, które stwarzają okazję do głębszej refleksji i osobistego przeżywania utworów. Na tak rozumianą turystykę literacką składają się dwie podstawowe formy podróżowania: turystyka biograficzna i turystyka fikcji literackiej.

Badacze zjawisk turystycznych wprowadzili także wątek turystyki literackiej do obszernych studiów nad turystyką zrównoważoną. Zaproponowano drobne zmiany, które nie przekształcają w istotny sposób dotychczasowych ustaleń pojęciowych: , ,...] turystyka literacka jest rozumiana jako forma turystyki kulturowej, obejmująca wszystkie wyjazdy, dla których inspiracją są dzieła literackie i ich filmowe adaptacje, jak również życie ich twórców" (Kowalczyk, Kulczyk, 2010, s. 232).

Należy jeszcze dodać, że areną turystyki literackiej mogą być różne przestrzenie. Wędrowanie śladami fikcji literackich i biografii ich twórców przebiega w przestrzeniach literatury i w przestrzeniach literackich (Wawrzyniak, 2010). Najnowsze badania nad turystyką literacką nie przynoszą nowych rozstrzygnięć pojęciowych. Publikowane są opracowania o znacznej przydatności aplikacyjnej. Często analizuje się potencjał literacki właściwy konkretnym jednostkom przestrzennym (Roszak, 2016). Obiecująco rozwija się nurt podmiotowy, tzn. obserwacji i analiz zachowań oraz doświadczeń czytelnika-turysty podczas podróży (Korpysz, 2019). W pierwszej kolejności musimy bowiem zobaczyć czytelnika w rzeczywistej przestrzeni literatury, w której znalazł się jako wędrowiec. Wówczas czytelnik-turysta, przemierzając przestrzeń turystyczna, przemieszcza się pomiędzy punktami X i Y, które są atrakcjami turystycznymi lub innymi docelowymi obiektami zwiedzania. W wyniku otrzymamy trzy logiczne kategorie zachowań turystycznych:

- zachowania zaplanowane - turysta przemierza przestrzeń wyznaczoną trasą między obiektami X i Y; punkty na trasie są dokładnie ustalone i wszystko jest zaplanowane, np. poszczególne etapy zwiedzania;

- zachowania ukierunkowane - turysta zna lokalizację miejsc, które chciałby zobaczyć, jednak trasa pomiędzy nimi może się zmieniać w zależności od okoliczności, zainteresowań czy predyspozycji odwiedzającego;

- zachowania przypadkowe - turysta zna tylko punkt rozpoczęcia wyprawy, natomiast o tym, jaką wybierze drogę, decyduje przypadek; kierunek wyprawy zależy czasami od niespodziewanego impulsu; odwiedzający nie ma konkretnego celu wędrowania; wie, skąd wyrusza, a droga i cel są kwestią przypadkowych zdarzeń (Kaczmarek, Kaczmarek, 2015; Płocka, 2013).

W turystyce literackiej konieczna jest różnorodność w konstruowaniu produktu turystycznego. Należy dokonać rekompozycji turystyki literackiej, ponieważ miejsce i rodzaj literatury są podstawą doświadczeń turystycznych. Nie ma jednej uniwersalnej definicji turystyki literackiej, jest wiele rodzajów takiego typu podróżowania i nie można zawrzeć go w jednej formule. Stąd proponowane ujęcie aleatoryczne w Hawanie, ponieważ miejsce i literatura wymuszają taką postawę czytelnika-turysty. To przypadek odpowiadał za inspiracje wspomnianych we wstępie kubańskich dzieł literackich oraz za organizację współczesnej przestrzeni literatury w Hawanie.

Literatura piękna, przestrzeń, turystyka są obiektami zainteresowań badawczych w wielu dyscyplinach naukowych. Warto zatem rozejrzeć się wokół i dostrzec 
innych badaczy. Ciekawe stanowisko w zakresie przestrzennych powiązań literatury, przestrzeni i podróży reprezentują literaturoznawcy. Ich odkryciem jest geopoetyka. W prekursorskim ujęciu White'a (2011) oznacza ona poetyckie otwieranie się na świat, dostrzeżenie związków człowieka z Ziemią. W tradycyjnym rozumieniu turystyki literackiej zazwyczaj pomija się ideę geopoetyki, co nie jest dobrym rozwiązaniem, ponieważ wzbogaca ona geograficzne podejście badawcze, które obejmuje podróże literackie. Geopoetyka uwrażliwia czytelnika i podróżnika, wprowadza poetycki punkt widzenia do zamieszkiwanego i odkrywanego świata. Turystyka literacka i poetyka doświadczania przestrzeni często idą w parze ulicami miast. Ścieżki prowadzące przez obszary, obiekty napotykane przez turystów można uporządkować według kategorii poetyki doświadczania przestrzeni. Mamy bowiem do czynienia ze sprawczością literatury wobec konkretnych miejsc w przestrzeni geograficznej. Owa sprawczość przejawia się $\mathrm{w}$ praktyce nazywanej turystyką literacką, czyli podróżami wyznaczonymi biografią pisarza, miejscami, w których toczy się akcja utworów (Konończuk, 2014). Poetyka doświadczania przestrzennego oddziałuje na przebieg podróży literackich. W jej ramach można wyróżnić następujące kategorie:

- miejsca zapośredniczone - obszary/obiekty doświadczane według wzorca zapisanego przez twórcę (np. przewodniki literackie);

- przestrzenie bez śladu - obszary/obiekty, z których usunięto bohaterów; zostali oni wymazani z pamięci, nie pojawiają się $\mathrm{w}$ zapisach literackich; odbiorca poszukuje ich śladów;

- terytoria niedomknięte - obszary/obiekty przedstawione $\mathrm{w}$ formie tekstu kultury (literackiego), które są zaproszeniem przedłożonym odbiorcy i pobudzają do wyruszenia w podróż (spotkanie, doświadczenie rzeczywistości geograficznej, rozumienie odwiedzanych przestrzeni) (Kaczmarek, 2016).

Przedstawione w niniejszej części artykułu rozważania skłaniają do zadania pytania, gdzie skrywa się istota turystyki literackiej oraz jakie siły wypychają turystę z wygodnego domu i nakazują podróż do mniej lub bardziej egzotycznych przestrzeni literackich. Bez najmniejszych wątpliwości można wskazać czynniki sprawcze zachowań czytelnika-turysty. Stymulatorami takiego działania są charakter dzieła literackiego oraz koloryt, tajemniczość odwiedzanych obszarów, a także postawa przybywającego podróżnego. Przebieg podróży literackiej zależy także od relacji pomiędzy autorem a czytelnikiem. Odbiorca dzieła nie pozostaje bowiem bezwolnym czytnikiem tekstu. On kreuje swoje miejsca w odwiedzanych przestrzeniach literatury. Owa kreatywność zależy od intuicji, wyobraźni, wrażliwości czytelnika, czynnikiem wzmacniającym doświadczanie dzieła literackiego w miejscu jego wydarzania bywa zaś właśnie przypadek.

\section{PRZESTRZEŃ LITERATURY W HAWANIE}

Aleatoryczne konteksty turystyki literackiej w Hawanie nie są przypadkowe. Owo miasto, jako skomplikowana całość, składa się bowiem z różnorakich fragmentów, wymykających się klasycznym podziałom morfologicznym i społecznym, co jest konsekwencją złożonych uwarunkowań historycznych, geograficznych, kulturowych, obyczajowych. Literatura nie może być inna, przecież powstała w Hawanie i dotyczy tego poranionego miasta:

Ciągle jest gorąco. Chyba dopiero nad ranem upał trochę zelżeje. Zostawiłem tylko otwarte małe okno od południowej strony. Stamtąd też widać całe miasto, które ciemne i ciche, dusi się tam w dole w srebrnym świetle księżyca. Wygląda, jakby było zbombardowane i opuszczone. Rozsypuje się coraz bardziej, ale jest piękne to cholerne miasto, w którym tak wiele kochałem i również wiele nienawidziłem (Gutiérrez, 2019, s. 287).

Przylatując w porze nocnej, turysta dowiaduje się, że za chwilę wyląduje na lotnisku José Marti w Hawanie. Wokół jest rzeczywiście ciemno i widać tylko pojedyncze światła karaibskiej metropolii. Natomiast hala przylotów bywa gwarna i pełna czujności ideologicznej. Przybywający turyści są skrupulatnie sprawdzani. Pracownicy lotniska nadmiernie celebrują kontrolę paszportową i bagażowa, aby nie wpuścić na kubańską ziemię rozpustnych wrogów ustroju. W nocy nie zobaczymy radosnego, roztańczonego miasta. Jeśli zimową pora podróżny postawi stopy na hawańskiej ziemi, także odczuje nadmierny upał, ale noc zakryje jeszcze ruiny wielkiego $i$ „,cholernego" miasta:

Berta ma siedemdziesiąt sześć lat. Mieszka sama na ósmym piętrze, przedostatnim w takim wysokim budynku przy San Lázaro w Hawanie Centrum. Wychodzi na balkon i wpada w depresję. Wszystko dokoła jest jak po bombardowaniu. Same ruiny. W dole słychać tylko głuchy szum zdewastowanego miasta. Od pewnego czasu Berta przestała nawet otwierać drzwi na balkon (Gutiérrez, 2019, s. 287).

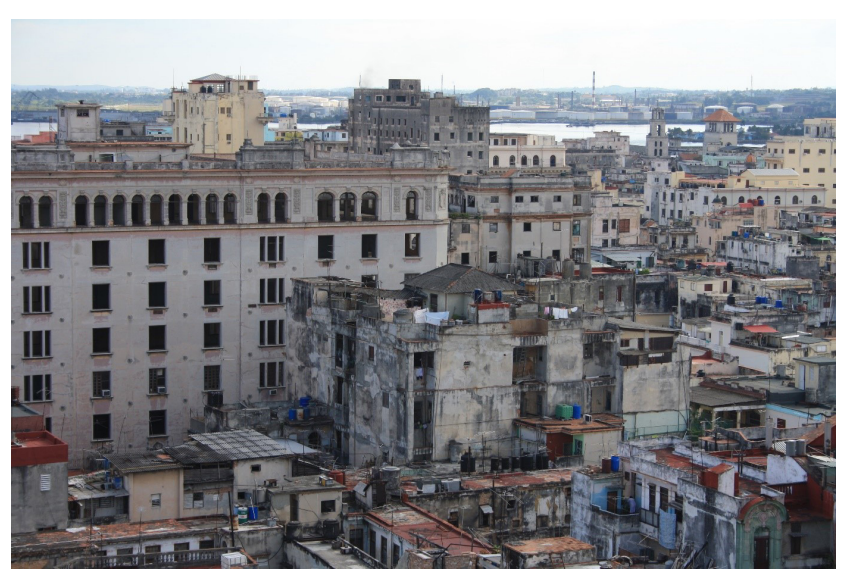

Fotografia 2. Panorama miasta z Edificio Bacardi Źródło: S. Kaczmarek (luty 2015) 
Centralna część Hawany wygląda przygnębiająco (fot. 2).

Turysta zachwyca się dawną świetnością Centro Habana. Wokół widać olśniewającą przeszłość. Spacer ulicą San Lázaro jest podróżą pomiędzy dwoma światami - dawnym i obecnym. Doskonale widać tam znakomitą przeszłość i ponurą teraźniejszość. Ludzie przysiadają na progach rozpadających się domów. Mieszkają w podzielonych lokalach, pod czujnym okiem domowych komitetów rewolucyjnych. Kubańczycy uśmiechają się i pozdrawiają obcych, zdecydowanie widocznych na San Lázaro. Piękny, uroczy, zmarnowany świat. Centro Habana jest także dobrym miejscem do obserwacji odwiedzanego, nieznanego świata:

Późnym popołudniem przygotowałem sobie szklankę mocnego rumu z lodem [...]. O tej porze wszystko staje się złociste, więc właśnie wtedy przyglądałem się światu. Na północy błękitne i nieprzewidywalne morze stworzone ze złota i nieba. Na południu i na wschodzie było stare miasto zniszczone i sponiewierane przez czas, sól, wiatr i ludzką niedbałość. Na zachodzie nowoczesne dzielnice z wieżowcami. Wszędzie inni ludzie, ich własny gwar i muzyka (Gutiérrez, 2019, s. 15).

Inne spojrzenie na Hawanę po wypitej szklaneczce rumu nie zmienia faktów. Zrujnowane miasto zniszczyło także umysły i dusze mieszkańców. Portugalczycy mają smutne oczy, Kubańczycy mają smutne dusze. Ich spontaniczna radość bywa złudzeniem i fasadą budowaną w obronie przed wzrokiem odwiedzających miasto: „[...] ja się zawsze cieszę, gdy trafiam na inteligentnych i pewnych siebie Murzynów, nie takich, którzy nigdy nie patrzą ci w oczy i mają tę swoją cholerną i pokurczoną mentalność niewolników" (Gutiérrez, 2019, s. 12). Zniszczenia w sercach i duszach Hawańczyków są przerażające. Klimat i komunizm zrujnują wszystko i wszystkich. Nawet nadzieja pozostaje pogrzebana w ruinach domów usytuowanych wzdłuż bulwaru Malecón. Życie toczy się z dnia na dzień. Łatwiej jest wypatrzyć Florydę, niż odnaleźć utraconą wiarę w życie: „Na co właściwie czekałem. Na nic. Czekałem. Tutaj wszyscy czekają. Dzień po dniu. Nikt nie wie, na co czeka. Dni mijają. I mózg powoli tępieje. To dobrze. Dobrze jest mieć otępiały mózg, bo wtedy się nie myśli" (Gutiérrez, 2019, s. 329).

Hawana bywa złudzeniem. Z wierzchu w Habana Vieja jest kolorowa, lukrowana, uprzejma (fot. 3), lecz jej wnętrze pozostaje puste, rozpadające się. Upudrowana twarz nie ma duszy.

Muzyka, która na Karaibach rodzi się z potrzeby serca, tutaj jest dobrze przygotowaną komercją. Wszystko jest na sprzedaż. Nawet szlachetność postaw, zachowań mocno potaniała: „Ale ubóstwo ma też inne twarze. Może najbardziej widoczna jest małoduszność, lub raczej zawężenie ducha. Stajesz się żałosnym, chciwym i wyrachowanym typem. Twoją jedyną troską jest

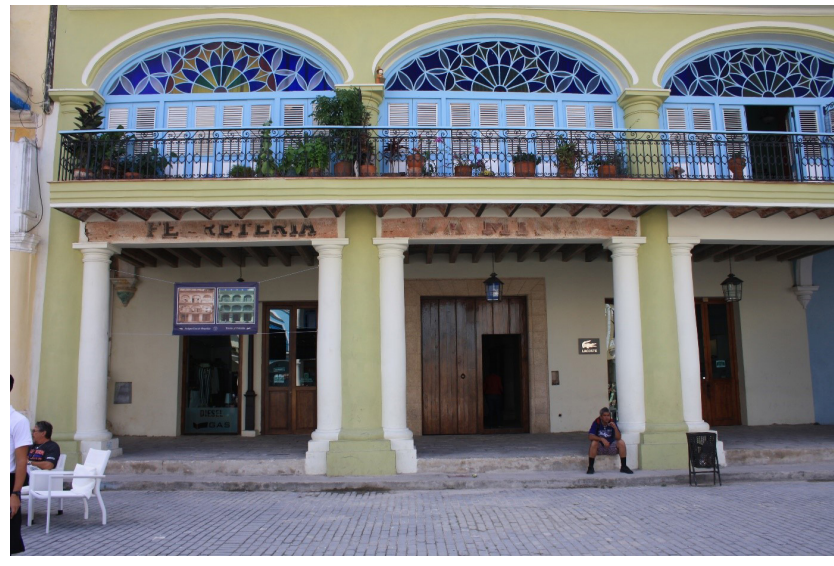

Fotografia 3. Habana Vieja

Źródło: S. Kaczmarek (luty 2015)

przeżyć. Po diabła ci szlachetność, solidarność, uprzejmość, pacyfizm" (Gutiérrez, 2019, s. 210).

Uliczny festiwal wyciągania pieniędzy od otumanionych turystów trwa nieprzerwanie. Turystom wydaje się, że dotarli do kubańskiego raju. Tylko hawańczycy są jacyś smutni. Trudno jest uwierzyć w autentyczność wszechobecnej salsy. Nawet rum i cygara są tylko towarem. Legenda tych produktów zniknęła niezauważona. Postawa mieszkańców Hawany nie pojawiła się bez przyczyny. To nie charakter Kubańczyków wywołuje zachowania opisane w Brudnej trylogii o Hawanie. Kubańczycy nie mieli po prostu alternatywy, stali się ofiarami komunizmu. Trudno być szlachetnym człowiekiem, kiedy głód zabija wszelkie uczucia:

Już wtedy na Kubie zaczynał się najgorszy głód w historii. Było to w dziewięćdziesiątym pierwszym. [...] Było to w lipcu albo sierpniu dziewięćdziesiątego czwartego. Od czterech lat w całym kraju panował głód i ogólny obłęd, ale najbardziej dotknęło to Hawanę. [...] Kryzys był naprawdę głęboki i dotykał nas wszystkich, przenikając cały nasz umysł i duszę (Gutiérrez, 2019, s. 41, $45,162)$.

W takich warunkach, gdy każdy dzień jest walką o przetrwanie, trudno zachować pogodę ducha i zabawowe postawy. Obecna sytuacja jest inna niż pod koniec XX w., jednak bolesne rany pozostały. Wędrowanie ulicami Hawany przypomina czasami dark tourism, usuwając w cień refleksyjna, akademicką turystykę literacką.

Na ulicach Hawany uważny wędrowiec dojrzy znaczne zróżnicowanie egalitarnego społeczeństwa socjalistycznego. Rzeczywiście, pewnym krokiem, z podniesioną głową maszerują biali Kubańczycy. Kolor skóry jest bez wątpienia przepustką do kariery. Spotyka się wielu umundurowanych funkcjonariuszy. Oni także czują się pewnie w tych zrujnowanych i uroczych jednocześnie fragmentach Centro Habana. Przecież ktoś musi pilnować socjalistycznego porządku. Turyści mijają ten piękny, zmarnowany świat. 
Przedstawione fragmenty Brudnej trylogii o Hawanie nie pozostawiają złudzeń, literackie wędrowanie po tym mieście nie może być elegancka, spokojna, rozważną turystyką. To powinno być właśnie aleatoryczne, namiętne i brudne doświadczanie miasta, jak szybki, powodujący niemożność złapania tchu seks w ruinach wspaniałych kiedyś domów: „Seks jest wymianą płynów i fluidów; seks to ślina, zdyszany oddech, ostre zapachy, mocz, sperma, gówno, mikroby i bakterie. Albo nie ma seksu. Jeśli seks ogranicza się do czułości, eterycznych nastrojów i uduchowienia, jest po prostu niczym" (Gutiérrez, 2019, s. 10).

Turystyka literacka dla wrażliwych, delikatnych turystów jest w Hawanie nieporozumieniem. Życiem w tym kochanym i nienawidzonym mieście kieruje przypadek. Hawana nie jest cukierkową atrakcją dla turystów wędrujących szlakami literackimi, z ogólnoświatowymi przewodnikami przed nosem. Uduchowiony, elegancki turysta powinien pomaszerować w stronę rewitalizowanej starej części miasta, tej pocztówkowej imaginacji kubańskiego raju (fot. 4).

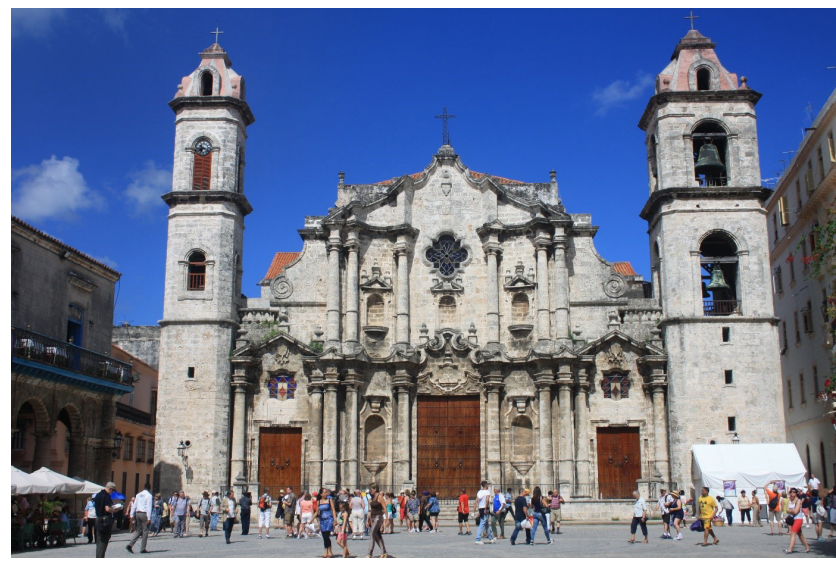

Fotografia 4. Plac Katedralny Źródło: S. Kaczmarek (luty 2014)

Hawany trzeba dotknąć poza utartymi szlakami. Spacer zaniedbaną i ekscytującą jednocześnie Avenida de Belgica zaprowadzi nieśpiesznego wędrowca w okolice Kolejowego Dworca Centralnego - miejsca raczej rzadko odwiedzanego przez cudzoziemców. Przypadkowy turysta może spokojnie obejrzeć imponujący budynek w stylu art déco, z początku XX w. Nad peronami wznoszą się imponujące nitowane, stalowe konstrukcje. Dawne życie tego miejsca gdzieś się zagubiło. Pozostało niewiele połączeń pasażerskich. Obok dworca można odpocząć na skwerze. Jeśli przypadkowy turysta przysiądzie na ławce, na chwilę stanie się częścią zwyczajnej, codziennej Hawany. Przychodzą tutaj okoliczni mieszkańcy i zagabują tych, którzy ewidentnie są obcy na tym obszarze. Jedni piją wódkę, inni spacerują z rodzinami. Próbują nieśmiało rozmawiać po hiszpańsku. Turysta chociaż na moment staje się częścią mniej znanego miasta i przez chwilę jest znajomym, niezależnie od stanu swojego portfela. Potrzebna bywa autentyczność, nawet wtedy, kiedy turysta wkracza na niebezpieczne obszary. Inaczej prawdziwe doświadczanie przestrzeni literatury w Hawanie zostanie zastąpione przez higieniczne zwiedzanie popularnych obiektów turystycznych.

Niektóre obszary Hawany były oceniane przez pisarzy podobnie mimo upływu lat. Na przykład aleja San Lázaro w latach 50. XX w. również nie wzbudzała zachwytu. Nie była jednak ruina, przerażającym obszarem, sceną życia wielu osób, które przybyły do stolicy Kuby:

Wróciliśmy dla odmiany, San Lázaro. Nie lubię tej ulicy, chcę przez to powiedzieć, że na pierwszy rzut oka, z początku, wygląda wielkomiejsko, jak ulica w Paryżu, Madrycie czy Barcelonie, ale zaraz okazuje się przeciętna, głęboko prowincjonalna, a przy parku Maceo rozszerza się $\mathrm{w}$ jedną $\mathrm{z}$ najbardziej przygnębiających i najbrzydszych alei w Hawanie. Bezlitosna w słońcu, mroczna i nieprzyjazna noca, ma tylko parę przyjemnych miejsc, Prado, Beneficiencia i jeszcze schody uniwersytetu (Cabrera Infante, 2016, s. 346).

Kiedy turysta maszeruje aleją San Lázaro i zmierza w stronę dzielnicy Vedado, przy ulicy Neptuno, na niewielkim wzgórzu, zobaczy monumentalny budynek Uniwersytetu Hawańskiego. Uwagę przykuwa rzeźba Alma Mater. Niesamowite wrażenie robią także majestatyczne schody. W przewodnikach turystycznych często pojawia się informacja, że jest to popularne miejsce spotkań (fot. 5). Osobiste doświadczenia mogą zaskakiwać. W dni wolne od pracy schodów pilnie strzeże umundurowany funkcjonariusz i zakazuje wstępu na teren uczelni, ale są one urokliwe.

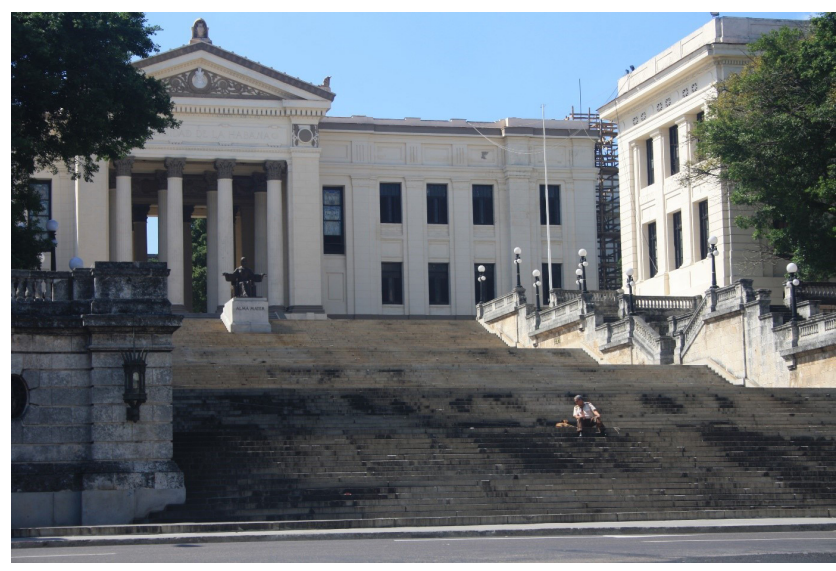

Fotografia 5. Uniwersytet w Hawanie Źródło: S. Kaczmarek (luty 2014)

Obszary funkcjonalne zmieniają swoje położenie w przestrzeni. Współczesny czytelnik-turysta może nie odnaleźć miejsc opisywanych na kartach książek, ponieważ ich lokalizacja uległa zmianie: 
To było po prostu centrum, i już. Potem to centrum przeniosło się na Prado, tak jak wcześniej musiało być na placu Katedralnym czy na Plaza Vieja, czy przy Ratuszu. Z upływem lat szło w górę aż do Galiano i San Rafael i Neptuno, a teraz jest na La Rampie. Zastanawiam się, gdzie w końcu zajdzie to wędrowne centrum, które co ciekawe, przesuwa się tak jak miasto i jak słońce, ze wschodu na zachód (Cabrera Infante, 2016, s. 338).

Nowe obszary funkcjonalne są lepiej utrzymane niż stare i przyciagają ciekawszych ludzi. Zlokalizowane są tam różne usługi. Dzielnica nabiera wówczas charakteru fragmentu metropolii. Na La Rampa panuje wzmożony ruch. Wprawdzie przeważają dawne amerykańskie limuzyny i radzieckie samochody, ale pojawiają się także nowe auta znanych marek. Ulica wygląda jaśniej, odczuwa się swobodniejszą i radosną atmosferę. Kuba zaczyna się zmieniać. Jest to widoczne w przestrzeni miasta: „Potem sprowadził nas po tym kawałku ulicy, który Kubańczycy nazywają La Rampa, pełnym sklepów, świateł i ludzi chodzących w dół i w górę. Jest całkiem w porządku" (Cabrera Infante, 2016, s. 192). Nie na wszystkich obszarach sytuacja wygląda w ten sposób. Taki bywa los miejsc tracących swoje ważne funkcje: „Aż wreszcie wszystko zaczęło się kończyć. Powoli. Dzielnica [Centro Habana - przyp. J.K] przestała być tym, czym była dawniej. Zamieszkali ją już inni ludzie: prymitywni Murzyni i najrozmaitsze chamstwo przybyłe z prowincji" (Gutiérrez, 2019, s. 412).

W odkrywaniu przestrzeni literatury w Hawanie nie może zabraknąć miejsca emblematycznego, czyli bulwaru Malecón. Spacer brzegiem morza od portu do Vedado powinien być aleatoryczny. Wskazane jest, aby zbieraniem doświadczeń turystycznych na Malecón rządził przypadek:

Najcudowniejszą rzeczą na świecie jest iść przed siebie Malecónem, podczas gdy dokoła szaleje cyklon. Idziesz i czasami myślisz. Czasami nie myślisz. Lepiej jest nie myśleć, ale to bardzo trudne, prawie niemożliwe. Trzeba mieć wprawę. [...] Teraz deszcz zmienił się w prawdziwe oberwanie chmury. Na całym Malecónie nie ma żywej duszy. Jest dopiero piąta, ale przez to zasnute niebo zrobił się już niemal wieczór. Szare, zimne i wilgotne światło, niezwykłe na tej wyspie, zawsze pełnej ostrego i rażącego blasku. Blada poświata sącząca się przez kurtynę deszczu, soli i jodu. Chowam się za słupem i czekam, aż trochę ulewa zelżeje (Gutiérrez, 2019, s. 138)

Malecón jest w pierwszej kolejności salonem Hawany, miejscem spotkań. Widuje się tam każdego, niezależnie od tego, kim jest i skąd pochodzi. Na tym bulwarze pojawiają się przedstawiciele wielkiego świata i podejrzani osobnicy z kubańskiego półświatka. Aby poznać Hawanę, trzeba spędzić sporo czasu na murku przy Malecón. Tutaj ludzie nawiązują podejrzane znajomości i tworzą chwilowe związki. Ten bulwar jest społeczną Hawaną w pigułce (fot. 6).

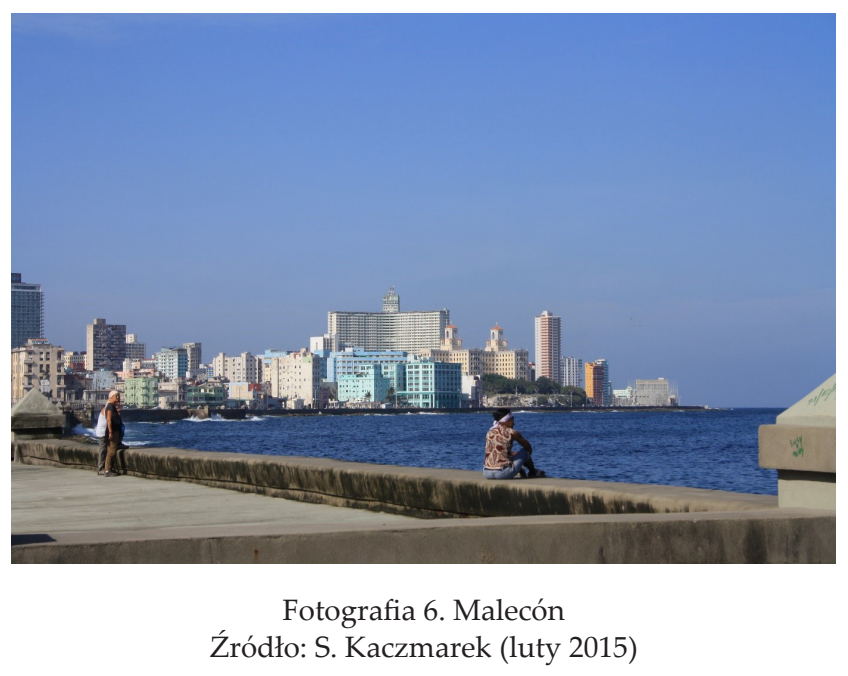

Kiedy skierujemy swoje kroki na Malecón, koniecznie trzeba się poddać losowi: „Dobre parę godzin rozmawialiśmy na Malecónie i podobaliśmy się sobie coraz bardziej. Żartowaliśmy, śmialiśmy się, trochę się z sobą droczyliśmy. O pierwszej w nocy moglibyśmy już przysiąc, że znamy się od zawsze. Zamilkliśmy na chwilę" (Gutiérrez, 2019, s. 59). Bulwar Malecón może być podziwiany lub można nim pogardzać (fot. 7), ale nie jest on obojętny zarówno dla mieszkańców, jak i dla turystów. Pobytu tam nie powinno się jednak planować.

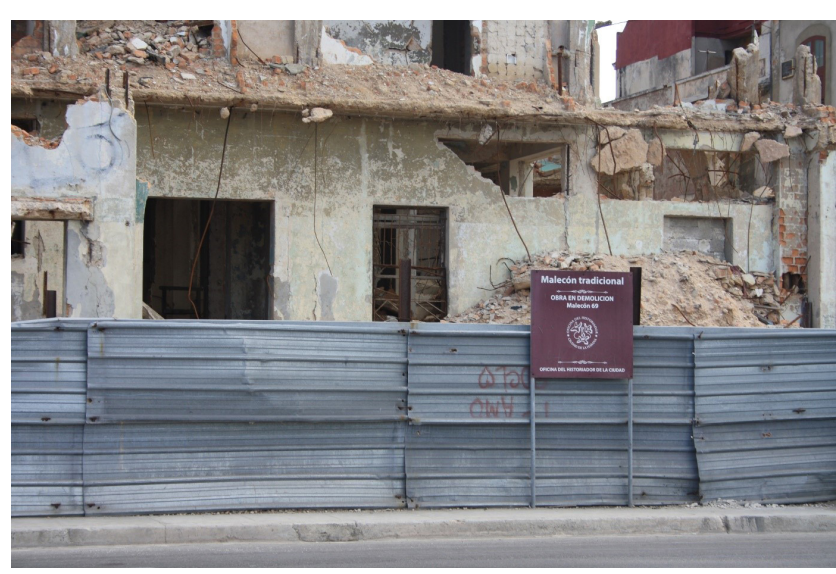

Fotografia 7. Malecón - ruiny bulwaru Źródło: S. Kaczmarek (luty 2015)

Turysta wędrujący na zachód bulwarem Malecón nieuchronnie zbliża się do majestatycznych wież Hotelu Nacional de Cuba:

Hotel był świetny. Co prawda, kosztował drogo, ale wart był swojej ceny. Jeśli Kubańczycy nauczyli się czegoś od nas, to jest to wyczucie komfortu, a Nacional to luksusowy hotel, co więcej, obsługa jest tam bez zarzutu. Obudziliśmy się po zmroku i wyszliśmy na spacer w pobliżu hotelu (Cabrera Infante, 2016, s. 191).

Hotel Nacional de Cuba pozostał legendą i luksusowym, pożądanym miejscem pobytu. Budynek jest 
rzeczywiście wspaniały i przyciąga turystów obiecanym luksusem. Mimo renowacji i przywrócenia dawnej świetności współcześnie hotel nosi piętno komunistycznej ideologii. Personel ma maniery charakterystyczne dla socjalistycznej przedsiębiorczości. Obsługa pracuje wolniej niż w innych sieciowych hotelach i bardziej myśli o swoich interesach niż o potrzebach gości. Kubańska legenda chwieje się w posadach, przebywający tam chwilowo odwiedzający nie zauważą jej fasady. Dłuższy pobyt pozwala dostrzec wiele pęknięć. Pozostaje sentyment i patrzenie z przymrużeniem oka na irytujący i piękny obiekt. Cóż, legendy bywają kapryśne.

Cabrera Infante i Gutiérrez odwołują się do podobnych miejsc zabawy i do odbywających się tam wydarzeń:

Chcieliśmy zobaczyć Tropicanę, Night-Club, który reklamuje sam siebie jako „najwspanialszy kabaret świata". Dla Pani Campbell stanowiła niemal jedyny powód tej podróży (Cabrera Infante, 2016, s. 207)

Wstąpiłem do Las Vegas. Las Vegas jest wieczne. Zawsze tam było, jest i będzie. To właśnie w Las Vegas ona śpiewała bolera. W kącie jest wciąż to samo pianino, tak samo stoją butelki pod barem, tak samo rum podają z lodem (Gutiérrez, 2019, s. 182).

Miejsca zabaw pozostają w Hawanie niezmienne. We wspomnianym Hotelu Nacional odbywają się różne ekscytujące przedstawienia. Interesujący jest np. koncert zespołu Grupo Compay Segundo, podkreślającego swoje powiązania z Buena Vista Social Club. Występ był zorganizowany sprawnie. Na scenie królowała salsa. Cena nie była zbyt wygórowana, tylko 25 CUC. Kiedy indziej godny zobaczenia jest Cabaret Parisien w rewiowym spektaklu o historii Kuby. Po koncercie zespół proponuje wspólny wieczór taneczny w rytmach salsy i samby. Warto skorzystać z takich propozycji. Zabawa trwa, niezależnie od czasu. Turysta może zażyć więc rozrywki nie tylko w opisywanym Las Vegas, ale także w wielu innych lokalach.

Literatura kubańska ma swój rytm nakreślony piórem autorów. Uważne czytanie i wczucie się w brzmienie słów pozwala odkryć rytm muzyczny w omawianej literaturze. W nowelach Cabrery Infantego brzmi cza-cza. Rytm literatury powinien wpływać na tempo zwiedzania miasta. Trzeba uważnie czytać i słuchać, aby dać się prowadzić w rytmie cza-czy: „Spojrzała na mnie. Spojrzała na mnie oczami w kolorze opala oliwy moczu. Spojrzała na mnie, jedząc i uśmiechając się. Jadła w sposób prawie doskonały, jeśli pominąc drobny amerykanizm, który kazał jej przekładać widelec z lewej ręki do prawej [...]" (Cabrera Infante, 2009, s. 47)

Muzyka rozbrzmiewa w Hawanie na każdym kroku. Nawet jeżeli grana jest z pobudek komercyjnych, to jej korzenie pozwalają odsłonić sens kubańskości. Nie można dać się zwieść fasadowości Kuby i Hawany. Miasto można odkryć, tylko trzeba je przedtem zrozumieć. Dobrą drogą do osiągnięcia tego celu jest literatura piękna.

Turystyka literacka w Hawanie musi być spontaniczna, w intuicyjnym podążaniu czytelnika-turysty. Kubańscy pisarze pozostawili uchylone odrapane drzwi do swojego miasta, do przeżytej przez nich obskurnej, wulgarnej Hawany: „Najlepsza jest zawsze naga rzeczywistość. Surowa i brutalna. Taka, jaką widzisz dookoła na ulicy. Chwytasz ją w ręce, dźwigasz - jeśli starczy ci siły - i przenosisz na papier. I już. Tylko tyle. Żadnych retuszy" (Gutiérrez, 2019, s. 141) (fot. 8). Do takiej właśnie przygody autorzy zapraszają czytelników swoich książek. Akademicka, higieniczna, uporządkowana turystyka literacka w Hawanie po prostu się nie sprawdza.

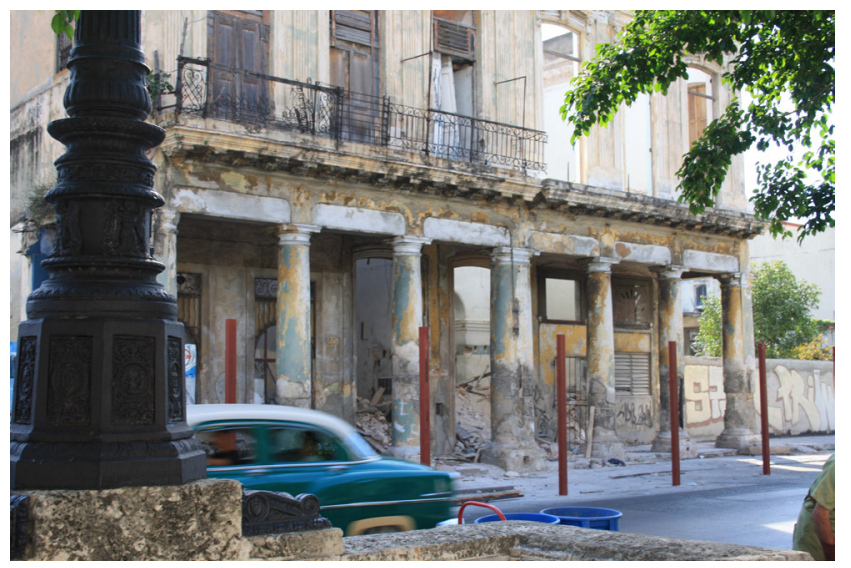

Fotografia 8. Zniszczona Stara Hawana Źródło: S. Kaczmarek (luty 2015)

\section{PODSUMOWANIE}

W turystyce literackiej czas jest kluczową kategorią poznawczą i doświadczaną. Bez ujęcia temporalnego wyjaśnianie zjawisk powiązanych z wędrowaniem śladami literatury pięknej bywa znacznie uproszczone lub staje się niemożliwe:

Cué miał obsesję czasu. Chcę powiedzieć, że szukał czasu w przestrzeni i niczym innym jak poszukiwaniem były nasze bezustanne, niekończące się podróże, jedna wieczna podróż po Malecónie, jak teraz, ale też o każdej porze dnia i nocy, przemierzaliśmy dziurawy krajobraz, ten między parkiem Maceo i La Punta, ze starymi domami, które stały się tym, co człowiek zabrał morzu, żeby zbudować Malecón: jeszcze jednym pierścieniem raf wydanym na działanie soli i wilgoci w dni, kiedy są fale i wiatr, a morze wskakuje na ulicę i zwala się na domy, przychodzi po wybrzeże, które mu zabrano, tworzy je, robi sobie drugi brzeg, potem były parki [...], następnie bary portowe, [...] i kościół Świętego Franciszka, przy klasztorze, naprzeciwko Giełdy i Urzędu Celnego, ślady różnych epok i dominacji odciśnięte 
na tym placu, [...] zjeżdżaliśmy w tunel pod zatoką i wpadaliśmy do Matanzas na kolację, [...] cały czas filozofując, estetyzując, moralizując, $[\ldots]$ - i zawsze mieliśmy czas na rozmowy o czasie (Cabrera Infante, 2016, s. 332-333).

W turystyce literackiej czas powinien być potraktowany dwojako. Po pierwsze mamy do czynienia z czasem opowieści literackiej. Jest to czas autora i wydarzeń przez niego opisanych. Po drugie dostrzegamy czas doświadczenia czytelnika-turysty. Wędrowiec podąża czasem opowieści literackiej, ale jednocześnie konstruuje swój własny, mający swoisty przebieg, specyficzny czas doświadczania literatury w podróży. W przyjmowanych definicjach turystyki literackiej takie różnicowanie czasu tworzenia literatury i jej doświadczania w podróży jest zazwyczaj niwelowane. Wszystko staje się jednolite, pozbawiane zróżnicowanych tonów opisywania i odczytywania. Po prostu brakuje subtelnych odcieni opisu wyruszania w podróże literackie. Nawiązując do opowieści o życiu w niepowtarzalnym szwajcarskim kurorcie, przedstawionej na kartach Czarodziejskiej góry, owo zanurzanie się w czasie można nazwać konstruowaniem osobliwego krajobrazu doświadczania turystycznego w miejscach literackich:

Życie stwarza czasem takie sytuacje, takie krajobrazy (jeśli wolno nazwać "krajobrazem” to, co mamy w tej chwili na myśli), w których takie pomieszanie i zatarcie czasowo-przestrzennych odległości, doprowadzające do zawrotnej jednolitości wszystkiego, jest faktem naturalnym, usprawiedliwionym; i wtedy nie należy potępiać kogoś, kto w godzinach wolnych od zajęć zanurza się w ich czarze. Mamy na myśli przechadzkę brzegiem morza [...]. Idziesz, i idziesz... z przechadzki takiej nigdy nie wrócisz na czas do domu, boś zgubił czas, a czas zgubił ciebie (Mann, 1982, s. 244-245).

Turysta podąża w swoim czasie, ale poszukuje czasu opowieści literackiej. W rezultacie konstruuje własny, doświadczany czas. Wędrowanie czytelnika-turysty, jego przemieszczanie się, jego ruch nadają sens przestrzeni. Czas turysty kreuje bowiem przestrzeń turystyczną. Warto powrócić do wspomnianej wcześniej myśli Ingardena, który stwierdza, „że właśnie analiza tekstu $\mathrm{z}$ ujawnieniem $\mathrm{w}$ nim miejsc niedookreślenia tudzież z jasnym uświadomieniem sobie, co tekst pozytywnie ustala w odniesieniu do rzeczywistości przedstawionej i do sposobów naocznego jej uchwytywania - pozwala wytyczyć granicę poprawności konkretyzacji [...]" (Ingarden, 1964, s. 201; zob. też: Kobiela, 2011). Owe różne porządki temporalne mogą się wówczas spotkać w odnalezionych przestrzeniach literatury.

Podążając szlakami inspiracji T. Manna, możemy przyjąć, że „krajobraz literacki” jest efektem doświadczania literatury w podróży przez czytelnika-turystę. Ścieżki odkrywania dzieła w przestrzeni są indywidualnym, osobistym jej doświadczaniem. Niestety wytyczane literackie szlaki turystyczne bywają ranami zadanymi miastom i regionom, przez które przebiegają. Zabliźnione rany pokazują przemoc oddziałującą na myślenie i postępowanie turystów. Przewodniki turystyczne narzucają sposób postrzegania otaczającej, odwiedzanej rzeczywistości. Stają się one także opatrunkami przyklejanymi na poranione miejsca. Owe rany są wynikiem zatracania oryginalności miejsc, do których się przybywa. Turyści nie są tam autentyczni (Kaczmarek, 2018), ponieważ myślą treścią przewodników i idą wytyczonym przez innych szlakiem. Oczywiście podążanie szlakiem turystycznym wyznaczonym przez kogoś, kto narzuca sposób myślenia, w znacznym stopniu wpływa na postrzeganie. Opatrunki zakłada się na miejsca poranione, na rany zadane przestrzeni przez "wandalów w sandałach" (Lowry, 2018, s. 231), którzy maszerują i pogłębiają bruzdy w schorowanych obszarach turystycznych. Potoki turystów, te dawne i te przychodzące, powodują pogłębienie owych bruzd. Kolejne szlaki, nowe tablice informacyjne rozdrapują zabliźniające się rany. Opisywane poranienie przestrzeni turystycznych jest konsekwencją pozbawienia odwiedzanych miejsc ich właściwości. Stają się one takie same dla każdego przybysza, który chodzi wyznaczonymi szlakami i posługuje się językiem przewodników, z których korzysta, szukając opisanych wrażeń. Zaplanowanie i pełne odsłonięcie tego, co powinno pozostać indywidualnym doświadczeniem i własnym odkrywaniem, w efekcie ujednolica obszary, ponieważ narzuca sposób ich odczytania.

Intymność, tajemnica, wrażliwość stają się towarem, przestają być osobistym doświadczaniem przestrzeni literatury. W związku z tym aleatoryczne ujęcie doświadczenia turystycznego może stać się remedium na rany zadawane odwiedzanym przestrzeniom. Autentyczny wędrowiec sam myśli, sam poznaje i osobiście odkrywa literaturę piękną w odwiedzanych miejscach. Wówczas mamy do czynienia $\mathrm{z}$ doświadczeniem indywidualnie konstruowanym, nie zaś zaplanowanym i narzuconym. Ostatecznie autor dzieła i czytelnik-turysta razem kreują poznawaną przestrzeń literatury.

\section{BIBLIOGRAFIA}

Arystoteles (2003). Fizyka. W: Arystoteles, Dzieła wszystkie (s. 23-204). T. 2. Tłum. K. Leśniak. Warszawa: Wydawnictwo Naukowe PWN.

Botterill, D., Platenkamp, V. (2012). Key concepts in tourism research. Londyn: SAGE.

Buczkowska, K. (2008). Turystyka kulturowa. Przewodnik Metodyczny. Poznań: AWF im. Eugeniusza Piaseckiego w Poznaniu.

Cabrera Infante, G. (2009). Moja wina, bo tańczyłem cza-czę. Tłum. U. Kropiwiec. Warszawa: Muza.

Cabrera Infante, G. (2016). Trzy pstre tygrysy. Tłum. U. Kropiwiec, T. Pindel. Kraków: Universitas. 
Cortázar, J. (2013). Gra w klasy. Tłum. Z. Chądzyńska. Warszawa: Muza.

Czermińska, M. (2000). Autobiograficzny trójkąt. Świadectwo, wyznanie, wyzwanie. Kraków: Universitas

Eco, U. (1994). Lector in fabula, współdziałanie w interpretacji tekstów narracyjnych. Warszawa: PIW.

Gutiérrez, P.J. (2019). Brudna trylogia o Hawanie. Tłum. P. Fornelski. Poznań: Zysk i S-ka.

Gwizdalanka, D. (1998). Przewodnik po muzyce kameralnej. Kraków: Polskie Wydawnictwo Muzyczne.

Heidegger, M. (1996). Przyczynki do filozofii (Z wydarzania). Tłum. B. Baran, J. Mizera. Kraków: Wydawnictwo Baran i Suszyński. Ingarden, R. (1964). W sprawie budowy dzieła literackiego: profesorowi Markiewiczowi w odpowiedzi. Pamiętnik Literacki, 55 (1), 183-202.

Kaczmarek, J. (2005). Podejście geobiograficzne w geografii społecznej. Łódź: Wydawnictwo Uniwersytetu Łódzkiego.

Kaczmarek, J. (2016). Spacer po terytoriach niedomkniętych, czyli śladami ekspresji geograficznych. Białostockie Studia Literaturoznawcze, 9, 237-255.

Kaczmarek, J. (2018). Autentyczność epistemologiczna jako nakaz moralny wyjaśniania rzeczywistości turystycznych. Folia Turistica, 49, 199-220.

Kaczmarek, S., Kaczmarek, J. (2015). Wielość rzeczywistości w przestrzeni turystycznej. Rozwój Regionalny i Polityka Regionalna, 31, 17-32.

Kobiela, F. (2011). Filozofia czasu Romana Ingardena wobec sporów o zmienność świata. Kraków: Universitas.

Konończuk, E. (2014). Między rzeczywistością a reprezentacją. Metafora mapy w powieściach Michela Houellebecqa Mapa i terytorium oraz Guillaume'a Jana Le Cartographe. W: E. Konończuk, E. Nofikow, E. Sidoruk (red.), Geografia i metafora (s. 175-195). Białystok: Wydawnictwo Uniwersytetu w Białymstoku.

Korpysz, A. (2019). Literackie obrazy Barcelony a doświadczenia turystów. Turystyka Kulturowa, 2, 34-46.

Kowalczyk, A., Kulczyk, S. (2010). Turystyka literacka. W: A. Kowalczyk (red.), Turystyka zrównoważona (s. 231-248). Warszawa: Wydawnictwo Naukowe PWN.

Lowry, M. (2018). Pod wulkanem. Tłum. K. Tarnowska. Poznań: Rebis.
Mann, T. (1982). Czarodziejska góra. T. 2. Tłum. J. Kramsztyk. Warszawa: Czytelnik.

Mikołajewski, J. (2011). Rzymska komedia. Warszawa: Agora.

Mikos von Rohrscheidt, A. (2008). Turystyka kulturowa. Fenomen, potencjat, perspektywy. Gniezno: GWSHM Milenium w Gnieźnie.

Milne, A.A. (1987). Chatka Puchatka. Tłum. I. Tuwim. Warszawa: KiW.

Pessoa, F. (2016). Poezje zebrane Álvaro de Campos. Tłum. W. Charchalis. Kraków: Lokator.

Płocka, S. (2013). Eksploracja przestrzeni turystycznej Paryża na przykładzie szlaków plenerów filmowych. Praca magisterska. Promotor J. Kaczmarek. Łódź: Instytut Geografii Miast i Turyzmu, WNG UŁ.

Roszak, J.M. (2016). Okiem przewodnika krajoznawcy. O potencjale turystyki literackiej w Hrubieszowie. Turystyka Kulturowa, 6, 6-18.

Roszak, J., Godlewski, G. (2013). Homo legens jako homo turisticus. Ku metodologii turystyki literackiej. Folia Turistica, $28,53-66$.

Schulz, B.(b.r.). Republika marzeń. Pobrane z: www.wolnelektury.pl (25.08.2019).

Stasiak, A. (2009). Turystyka literacka i filmowa. W: K. Buczkowska, A. Mikos von Rohrscheidt (red.), Wspótczesne formy turystyki kulturowej (s. 223-265). Poznań: AWF im. Eugeniusza Piaseckiego w Poznaniu.

Stein, E. (1995). Byt skończony a byt wieczny. Tłum. I. Adamska OCD. Poznań: W drodze.

Wasserstein, R.L., Schirm, A.L., Lazar, N.L. (2019). Moving to a World Beyond "p0,005”. The American Statistician, 73 (1), 1-19.

Wawrzyniak, M. (2010). Czytanie miasta - idea produktu turystyki literackiej na przykładzie Łodzi. Turystyka Kulturowa, 3, 16-29.

White, K. (2011). Zarys geopoetyki. Tłum. A. Czarnacka. Białostockie Studia Literaturoznawcze, 2, 7-25.

Wittgenstein, L. (2012). Tractatus logico-philosophicus. Tłum. B. Wolniewicz. Warszawa: Wydawnictwo Naukowe PWN.

Zajas, P. (2008). O „,autentyczności” i ponowoczesnym rozumieniu doświadczenia turystycznego. Teksty Drugie, 4, 215-230.

Zmyślony, P. (2000). Literatura jako podstawa tworzenia produktu turystycznego. Problemy Turystyki, XXIV (1-2), 21-31.

Artykuł wpłyną: 10 września 2019 r.

Zaakceptowano do druku: 22 kwietnia $2020 \mathrm{r}$. 